\title{
TOURISM DEMAND MODELING: PRICE AND INCOME ELASTICITY
}

\author{
A.H.G. Kusumah \\ (1)(2)(3) Program Studi Manajemen Resort \& Leisure \\ Universitas Pendidikan Indonesia \\ galih@,upi.edu
}

\begin{abstract}
This paper provides a tourism demand model that estimates the price elasticity of demand and income elasticity of demand in Australia, European Union (EU), and USA. The results show that Australia and EU tourists markets are price elastic, while USA market is slightly price inelastic. It indicates that both Australia and EU tourists markets are sensitive to the tourism price while USA market is not. The study also found that the income elasticity of demand from the three markets is relatively income inelastic. In other words, tourism demand in the three markets is unresponsive to a change in income.
\end{abstract}

\section{INTRODUCTION}

Over the decades, tourism has experienced continued growth and deepening diversification to become one of the fastest growing economic sectors. Although the tourism growth and demand has been established by many previous studies, analyzing the effect of income and price elasticity of specific country/region to international tourism is remains required. The tourism industry has played very important role in the economy development and it also faces a lot of challenges. Contrary to the symmetry assumption used in most of the tourism demand studies, there are important reasons why income and price effects may vary. For maintaining a sustainable competitive advantage, study related to the effect of income and tourism price to tourism demand is needed to bring the attention of the policymakers and planners. For achieving this, the determinants of international tourism demand should be assessed.

\section{THE MODEL}

Numerous of external factors such as political situation, natural disasters, destination image or war and terrorist attack can influence tourism demand. Some scholars argue that tourism demand is one of the most difficult variables to be predicted. Nonetheless, it is crucial for both destinations and private sectors to understand demand trends and use it as a basis of management decisions and planning. Most of previous studies on tourism demand analysis can be categorized into two groups, either non-casual (timeseries) modeling methods or casual (econometric) methods. The non-casual modeling methods forecast tourism demand trends in the future without reckon the trends' causes (Song, Witt \& Jensen, 2003) It is worth noting that the non-casual modeling method are not constructed from travelers' motivation theories, therefore, it cannot be utilized for policy evaluation purposes. On the contrary the casual modeling approaches play an important role to the factors that influence tourism demand. On the other hand, econometric methods are more superior in compare to time-series approach. It can provide a valuable observation related to tourism demand. Furthermore the specification of the model allows forecasts to assess how the tourism demand would respond if the determining factors change.

\section{Determinants of Tourism Demand}

Following the standard economic theory, the own price of the good, the price 
of a substitute good and consumers' income are the key variables for determining the demand for a consumer good. However, in this study, the price of substitute good is ignored. Therefore, the following equation is thus proposed to represent the demand for world's tourism from each origin country/region i :

$$
\mathrm{Q}_{i t}=A P_{i t}^{\beta 1} Y_{i t}^{\beta 3} e_{i t}
$$

In this study, tourism demand is represented as $Q_{i t}$ and measured by tourism import from country/region $i$ at time $t ; \quad P_{i t}$ is a relative consumer price level for country/region $i$ at time $t$ or own price, and $Y_{i t}$ is the GDP of the origin country/region $i$ at time $t$, and $e_{i t}$ is the residual term that used to depict the influence of other factors which have not to included into the model.

The dependent variable $Q_{i t}$ is measured by tourism demand from country $i$. The data for this study were obtained from Smeral (2012) study. The income variable $Y_{i t}$ is income in origin country/region $i$ measured by the index of real GDP $(2000=100)$. The definition of the own price variable can be measured by

$$
\mathrm{P}_{i t}=\frac{T P I_{i}}{P I_{i}}
$$

where $T P I_{i}$ is the import price index for country/region $i$ measuring the cost of traveling abroad and is a domestic price index measured by GDP deflator for country/region i. The variable is for measuring the cost of travelling relative to the origin country. It is noticed that the travel cost should be included the model. However, a lot of studies revealed that, the travel cost variable was insignificant in many of the tourism demand models (Song \& Li, 2008; Song, Witt, \& Jensen; Song, Won \& Chon, 2003b; Ayeh \& Lin, 2011).

\section{Specification of Econometric Model}

The model (Eq.1) was chosen because of two major reasons. Firstly, previous

$$
\begin{aligned}
& \ln Q_{i t}=\alpha_{0}+\alpha_{1} \ln Q_{i t-1}+\alpha_{2} \ln Q_{i t-2}+\alpha_{3} \ln P_{i t}+\alpha_{4} \ln P_{i t-1}+\alpha_{5} \ln P_{i t-2}+\alpha_{6} \ln Y_{i t} \\
& +\alpha_{7} \ln Y_{i t-1}+\alpha_{8} \ln Y_{i t-2}+e_{i t}
\end{aligned}
$$

studies suggested that the power model produce better model compare to single linear demand (Sheldon \& Var, 1985; Haiyan Song \& Stephen F. Witt, 2000; Haiyan Song \& Stephen F. Witt, 2003; Ayeh $\&$ Lin, 2011). Secondly, the researchers enable to launch the forecasting easily with the help of OLS because the power model can be transferred into a single long linear model. Furthermore, as Song and Witt (2000) explained, the estimated coefficients of the explanatory variables in the log linear model are the demand elasticities. After take logarithm of Eq. (1), a new equation is gained

$$
\ln Q_{i t}=\beta_{0}+\beta_{1} \ln P_{i t}+\beta_{2} \ln Y_{i t}+u_{i t},
$$

where $\beta_{0}=\ln A, \quad u_{i t}=\ln e_{i t}$, and $\beta_{1}$ and $\beta_{2}$ are price and income (GDP) elasticities. Based on the basic economic theory, the estimation expects $\beta_{1}<0$ which means the price of the travel has a negative influence on the demand while $\beta_{2}>0$ which reflects the income level of the origin country.

However, a forecasting model, Eq. (3) is still needs to be developed. It is because of the dynamic of tourist's decision process that affected tourism demand, therefore, the model must consider other factors including. ADLM (Autoregressive Distributed Lag Model), a more specific model, is adopted in this study. On the other hand, the tourism industry owns its characteristics, such as economic situation or government regulation. Furthermore, there is country/region specific condition such as Airline Deregulation Act in United State around late $70 \mathrm{~s}$ or economic crisis that may affect tourism demand. In order to achieve accuracy, all these events need to be involved into the model. Thus, there is an independency variable be introduced as dummies. To sum all these up, the simple Eq. (4) with ADLM could be written as 
Eq. (4) shows that the current tourism demand is influenced by current values of the explanatory variables as well as the lagged dependent and explanatory variables. This specification is more difficult to understand than the static demand model, as it takes into account the time path of tourists' decision-making process which can affected tourism demand. The reasons why to include the lagged variables are: firstly, the lagged-dependent can reflect how tourist's income and tourism price from previous year affect tourism demand, and secondly, the tourism demand in respective year depends on the tourism demand from previous years.

\section{Estimates of the demand models}

Previous studies (Ayeh \& Lin, 2011; Song, Wong \& Chon, 2003) used general-tospecific procedure as a testing down procedure. The first step is to use Eq. (4) and see if all the variables are statistically significant or not. The second step is to

$$
\ln Q_{i t}=\alpha_{0}+\sum_{j=1}^{p} \alpha_{j} \ln Q_{i t-j}+\sum_{j=0}^{p} \beta_{j} \ln Y_{i t-j}+\sum_{j=0}^{p} \delta_{j} \ln P_{i t-j}+d u m m i e s+\varepsilon_{i t},
$$

Table 1 presents the estimated final models for the three countries: Australia, E.U and USA. The results show that the lagged-dependent variable is significant in all the countries. This reveals that the demand of these three markets for world tourism is depends on the tourism import of previous years. Furthermore, income variable is significant in all the models. It indicated that the income level of these three countries is an important factor for the tourism demand. For USA market, study shows that income from previous years is affect market's decision to travel.

On the other hand, price level in all of three countries also has significant influence to tourism demand. Similar with the result of income variable effect, price level of previous year is significant for USA market. Therefore, we can conclude that tourism product price and income is an important determinant for tourism demand from these three countries. eliminate these insignificant variables one by one according to the $t$-statistics of the estimated coefficients starting from the least significant ones judged by their t-statistics. When the insignificant variables are all removed from the model, the model is assessed with a few diagnostic statistics which includes autocorrelation, heteroscedasticity, normality and forecasting ability. Finally the demand elasticity and forecasting are calculated in terms of the final model.

A number of dummies variables were considered to capture the influence of oneoff events on the demand for tourism. The first one is the US Airline Deregulation Act in late 70 s to early $80 \mathrm{~s}$. The rest of dummies were the 911 terrorist attacks in USA and the financial crisis in 1998 and 2008. These dummies take the value of 1 in the concerning year(s) which will be influenced by the event and 0 otherwise. Therefore the initial ADLM now is developed to:

Among all the one-time event dummy variables, the USA Airline Deregulation Act (ADA) in late 70 s to early 80 s is the only significant variable in USA markets. Surprisingly, as shown in the model, the rest of one-time event dummy variables are all insignificant. USA airline deregulation occurred during the Civil Aeronautics Board (CAB) shut down. CAB operated from 1938 to 1984 and involved in setting interstate routes as well as regulating fares for the commercial airlines. $\mathrm{CAB}$ had regulated all domestic interstate air transport routes as a public utility, setting fares, routes, and schedules. They earned a reputation for bureaucratic complacency; airlines were subject to lengthy delays when applying for new routes or fare changes, which were not often approved ("Civil Aeronautics Board (United States government agency) -Encyclopedia Britannica," n.d.). With the deregulation of the airline industry, however, the role of the $\mathrm{CAB}$ was much 
diminished and the tourism demand for USA was significantly increased after 1984.

Table 1 Estimate of Demand Models

\begin{tabular}{|c|c|c|c|}
\hline Variables & Australia & E.U & U.S.A \\
\hline Intercept & $\begin{array}{c}-8.271 \\
(-9.778)^{* *}\end{array}$ & $\begin{array}{c}-6.232 \\
(-3.139)^{* *}\end{array}$ & $\begin{array}{c}-2.320 \\
(-3.519)^{\star \star}\end{array}$ \\
\hline LNTEX,1 & $\begin{array}{c}0.305 \\
(3.523)^{\star *}\end{array}$ & $\begin{array}{c}0.541 \\
4.469)^{* *}\end{array}$ & \\
\hline LNTEX,2 & & & $\begin{array}{c}0.262 \\
(4.692)^{\star *}\end{array}$ \\
\hline LNPIT & $\begin{array}{c}-0.883 \\
(-9.126)^{* *}\end{array}$ & $\begin{array}{c}-1.288 \\
(0.283)^{* *}\end{array}$ & $\begin{array}{c}-1.093 \\
(-19.125)^{* *}\end{array}$ \\
\hline LNPIT2 & & & $\begin{array}{c}0.432 \\
(5.571)^{\star *}\end{array}$ \\
\hline LNGDP & $\begin{array}{c}1.109 \\
(9.345)^{\star \star}\end{array}$ & $\begin{array}{c}0.739 \\
(3.446)^{\star *}\end{array}$ & $\begin{array}{c}1.725 \\
(6.811)^{\star \star}\end{array}$ \\
\hline LNGDP,2 & & & $\begin{array}{c}-1.080 \\
(-4.226)^{\star \star}\end{array}$ \\
\hline DADA & & & $\begin{array}{c}-0.391 \\
(-11.414)^{\star *}\end{array}$ \\
\hline$R^{2}$ & 0.985 & 0.990 & 0.994 \\
\hline Adjusted $R^{2}$ & 0.983 & 0.989 & 0.993 \\
\hline F statistics & 624.726 & 875.428 & 707.201 \\
\hline KS Test & 0.105 & 0.137 & 0.060 \\
\hline SW Test & 0.949 & 0.970 & 0.966 \\
\hline
\end{tabular}

Note: The figures in parentheses are t-statistics. Dummy variable representing the Airline Deregulation period from the year $1977-1984$ is included in demand modeal. ${ }^{* *}$ and $*$ represents $1 \%$ and $5 \%$ significant levels respectively.

\section{Validity of the models}

Reviewing Adjusted $R^{2}$, F-statistic and Significant $F$ Change, all the three models passed the goodness-of-fit test. The diagnostic statistics showed that the three models passed all the tests. KS and SW significant tests for all countries are above 0.05 , therefore all of the models passed the normality tests. The DW statistics does not need to be considered as a lagged dependent variable is included in all the models.

\section{Elasticity of demand}

Based on the estimated demand models in Table 1, the demand elasticities were derived. Demand elasticities are very important indicators for both policymakers and business planners. Price elasticity is important indicators for the suppliers of tourism products and services since it has a direct on the tourist demands. When the tourism product is price elastic $(>1)$, then tourism product sales growth increases significantly with a decrease in price. On the other hand, if tourism product is inelastic $(<1)$, it means that sales growth will decrease with a reduction in price. Table 2 shows that U.S.A market is slightly price inelastic, while Australia and E.U are considered price elastic. It indicates that two out of three tourists markets are sensitive to the tourism price. On the other hand, the valued of the income elasticity conveys the responsiveness of the tourism demand to the change in the income level in the origin country. The result shows that all of the three markets are relatively income inelastic.

Table 2 Estimated demand elasticities

\begin{tabular}{ccc}
\hline Country & $\begin{array}{c}\text { Price } \\
\text { elasticity }\end{array}$ & $\begin{array}{c}\text { Income } \\
\text { elasticity }\end{array}$ \\
\hline Australia & -1.18867 & 0.803523 \\
E.U. & -1.829 & 0.198 \\
U.S.A & -0.923 & 0.383 \\
\hline
\end{tabular}

\section{CONCLUSION}

The study shows the demand of Australia, EU and USA markets for world tourism is 
depends on income level, tourism products price and the tourism import of previous years. Income variable in the respective year is significant in all the models of three countries and while for USA market, income from previous years is also affect market's decision to travel.

The tourism demand is influenced by the price level in all three countries. Similarly with income level, the price level of previous years is significant for USA market. Thus, we can conclude that tourism product price and income is an important determinant for tourism demand from these three countries. Therefore, tourism demand of Australia, EU and USA markets for world tourism is depends on income level, tourism products price and the tourism import of previous years. In addition, government intervention such as the influence of $\mathrm{CAB}$ in USA prior to 1984 has an important role to tourism demand.

The price elasticity reveals that tourists from Australia and EU are more sensitive to the price level comparing with tourists from USA when choosing their destination. On the other hand, the valued of the income elasticity conveys the responsiveness of the tourism demand to the change in the income level in the origin country. On the other hand, the study shows that all of the three markets are relatively income inelastic.

\section{REFERENCES}

Andy Field (2009) Discovering Statistics Using SPSS, 3rd Edition, Sage Publications Ltd

Ayeh, J. K., \& Lin, S. (2011). "Estimating tomorrow"s tourist arrivals': forecasting the demand for China's tourism using the general-to-specific approach. Tourism and Hospitality Research, 11(3), 197-206. doi:10.1177/1467358411415466

Civil Aeronautics Board (United States government agency) -- Encyclopedia Britannica. (n.d.). Retrieved March 14, 2014, from http://global.britannica.com/EBchecke d/topic/119198/Civil-AeronauticsBoard

Smeral, E (2012). International tourism demand and the business cycle. Annals of Tourism Research, 39(1), 379-400.

Song, H., \& Witt, S. F. (2000). Tourism demand modelling and forecasting: modern econometric approaches. Elsevier.

Song, H., Wong, K. K. F., \& Chon, K. K. S. (2003). Modelling and forecasting the demand for Hong Kong tourism. International Journal of Hospitality Management, 22(4), 435-451.

Song, H., Witt, S. F., \& Jensen, T. C. (2003). Tourism forecasting: accuracy of alternative econometric models. International Journal of Forecasting, 19(1), 123-141.

Song, H., \& Witt, S. F. (2003). Tourism forecasting: the general-to-specific approach. Journal of Travel Research, 42(1), 65.

Song, H., \& Li, G. (2008). Tourism demand modeling and forecasting $-A$ review of recent research. Tourism Management, 29(2), 203-220.

\section{Appendix One Australia}

Model Summary ${ }^{b}$

\begin{tabular}{|l|r|r|r|c|}
\hline Model & R & R Square & Adjusted R Square & $\begin{array}{c}\text { Std. Error of the } \\
\text { Estimate }\end{array}$ \\
\hline 1 & $.992^{\mathrm{a}}$ & .985 & .983 & .05692 \\
\hline
\end{tabular}

a. Predictors: (Constant), LNGDP, LNPIT, LAGS(LNTEX,1)

b. Dependent Variable: LNTEX 
ANOVA $^{\mathrm{a}}$

\begin{tabular}{|rl|r|r|r|r|r|}
\hline Model & & \multicolumn{1}{c|}{ Sum of } & df & Mean Square & $\mathrm{F}$ & \multicolumn{1}{c|}{ Sig. } \\
\hline \multirow{2}{*}{1} & Squares & & & & $.000^{\mathrm{b}}$ \\
& Regression & 6.072 & 3 & 2.024 & 624.726 & \\
& Residual & .094 & 29 & .003 & & \\
& Total & 6.166 & 32 & & & \\
\hline
\end{tabular}

a. Dependent Variable: LNTEX

b. Predictors: (Constant), LNGDP, LNPIT, LAGS(LNTEX,1)

Coefficients $^{a}$

\begin{tabular}{|c|c|c|c|c|c|c|}
\hline \multirow[t]{2}{*}{ Mod } & & \multicolumn{2}{|c|}{ Unstandardized Coefficients } & \multirow{2}{*}{$\begin{array}{c}\text { Standardized } \\
\text { Coefficients }\end{array}$} & \multirow[t]{2}{*}{$t$} & \multirow[t]{2}{*}{ Sig. } \\
\hline & & $B$ & Std. Error & & & \\
\hline \multirow{4}{*}{1} & (Constant) & -8.271 & .846 & & -9.778 & .000 \\
\hline & $\begin{array}{l}\text { LAGS(LNTEX, } \\
\text { 1) }\end{array}$ & .305 & . 087 & 280 & 3.523 & .001 \\
\hline & LNPIT & -.883 & .097 & -.301 & -9.126 & .000 \\
\hline & LNGDP & 1.109 & .119 & .822 & 9.345 & .000 \\
\hline
\end{tabular}

a. Dependent Variable: LNTEX

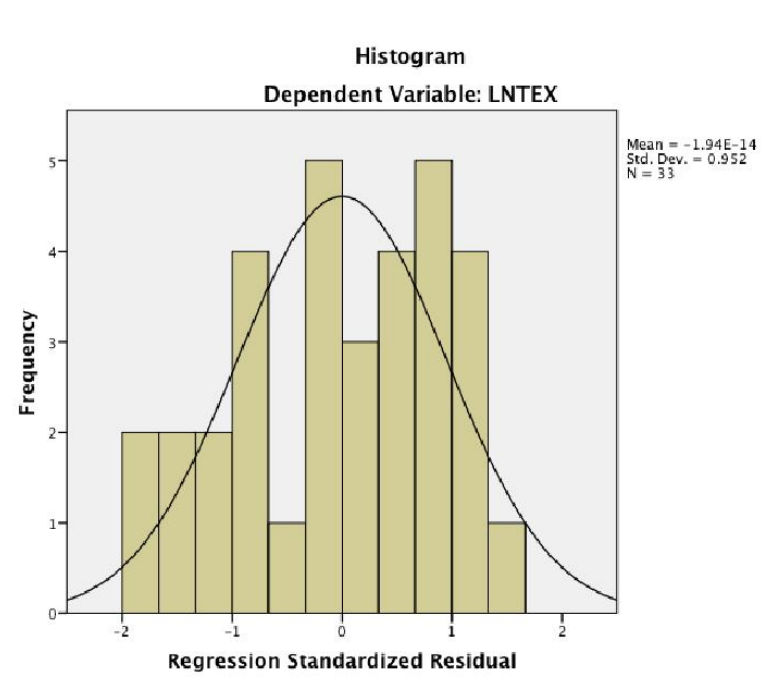

Normal P-P Plot of Regression Standardized Residual
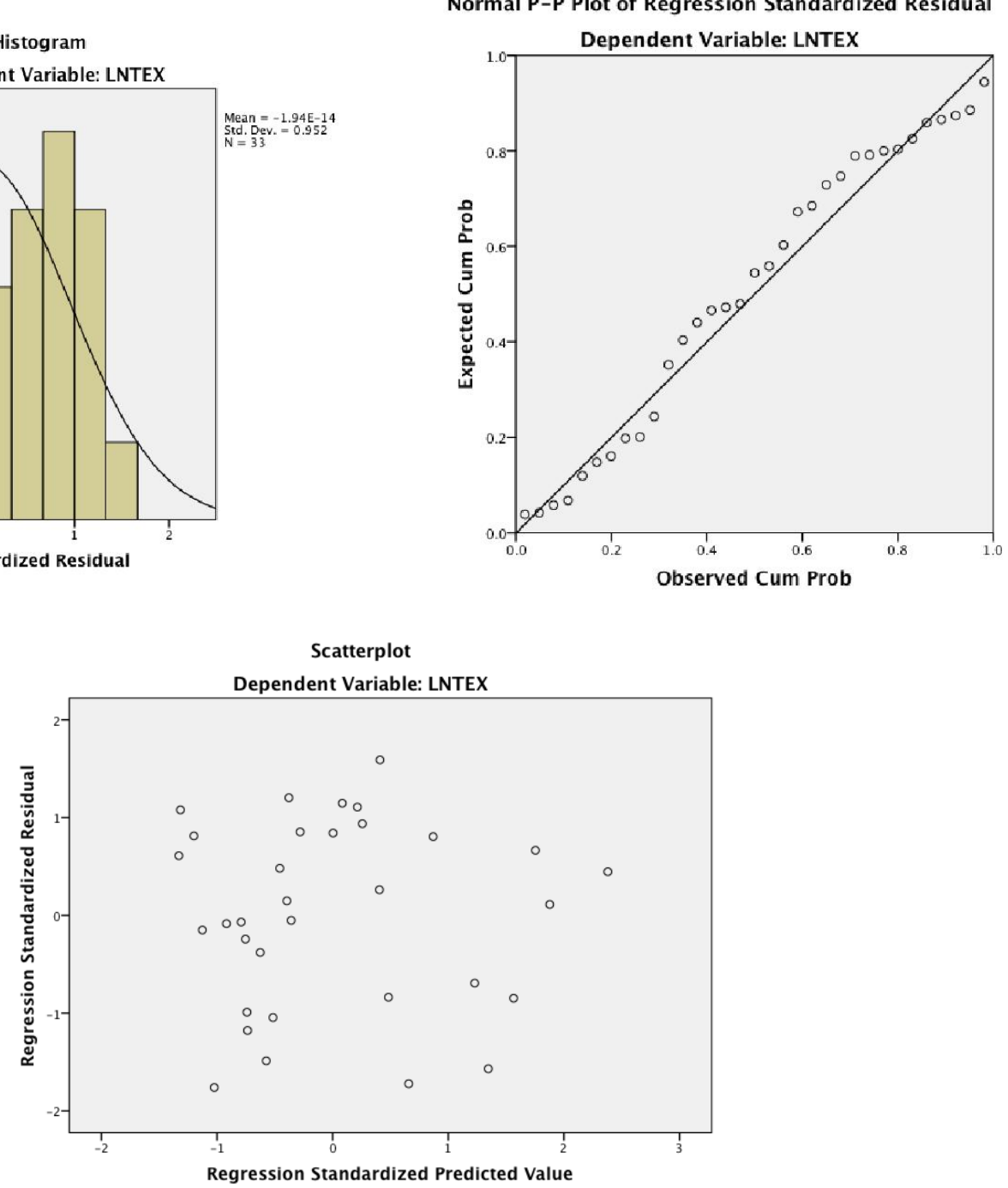
A.H.G. Kusumah: Tourism Demand Modeling: Price And Income Elasticity

Tests of Normality

\begin{tabular}{|l|r|r|r|r|r|r|}
\hline & \multicolumn{3}{|c|}{ Kolmogorov-Smirnova } & \multicolumn{3}{c|}{ Shapiro-Wilk } \\
\cline { 2 - 7 } & Statistic & \multicolumn{1}{c|}{$\mathrm{df}$} & \multicolumn{1}{c|}{ Sig. } & Statistic & \multicolumn{1}{c|}{ df } & \multicolumn{1}{c|}{ Sig. } \\
\hline Standardized Residual & .105 & 33 & $.200^{*}$ & .949 & 33 & .124 \\
\hline
\end{tabular}

${ }^{*}$. This is a lower bound of the true significance.

a. Lilliefors Significance Correction

\section{Appendix Two E.U}

Model Summary ${ }^{b}$

\begin{tabular}{|l|r|r|r|r|}
\hline Model & R & R Square & Adjusted R Square & $\begin{array}{c}\text { Std. Error of the } \\
\text { Estimate }\end{array}$ \\
\hline 1 & $.995^{\mathrm{a}}$ & .990 & .989 & .03730 \\
\hline
\end{tabular}

a. Predictors: (Constant), LNGDP, LNPIT, LNTEX1

b. Dependent Variable: LNTEX

ANOVA $^{a}$

\begin{tabular}{|rl|r|r|r|r|r|}
\hline Model & & Sum of Squares & df & Mean Square & F & Sig. \\
\hline \multirow{2}{*}{1} & Regression & 3.653 & 3 & 1.218 & 875.428 & $.000^{\mathrm{b}}$ \\
& Residual & .036 & 26 & .001 & & \\
& Total & 3.690 & 29 & & & \\
\hline
\end{tabular}

a. Dependent Variable: LNTEX

b. Predictors: (Constant), LNGDP, LNPIT, LNTEX1

Coefficients $^{\mathrm{a}}$

\begin{tabular}{|c|c|c|c|c|c|c|}
\hline \multirow[t]{2}{*}{ Mod } & & \multicolumn{2}{|c|}{ Unstandardized Coefficients } & \multirow{2}{*}{$\begin{array}{c}\begin{array}{c}\text { Standardized } \\
\text { Coefficients }\end{array} \\
\text { Beta }\end{array}$} & \multirow[t]{2}{*}{$\mathrm{t}$} & \multirow[t]{2}{*}{ Sig. } \\
\hline & & $B$ & Std. Error & & & \\
\hline \multirow{4}{*}{1} & (Constant) & -6.232 & 1.985 & & -3.139 & .004 \\
\hline & LNTEX1 & .541 & .121 & .553 & 4.469 & .000 \\
\hline & LNPIT & -1.288 & .283 & -.099 & -4.555 & .000 \\
\hline & LNGDP & .739 & .214 & .420 & 3.446 & .002 \\
\hline
\end{tabular}

a. Dependent Variable: LNTEX
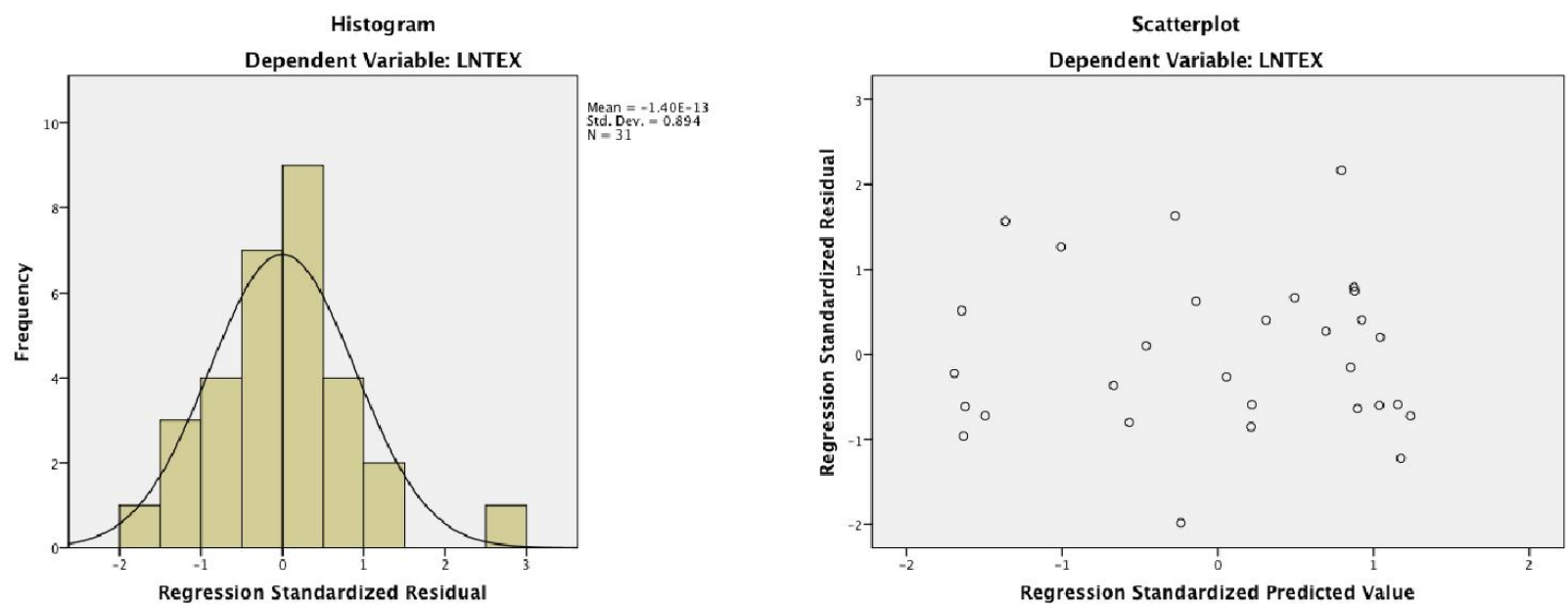
Normal P-P Plot of Regression Standardized Residual Dependent Variable: LNTEX

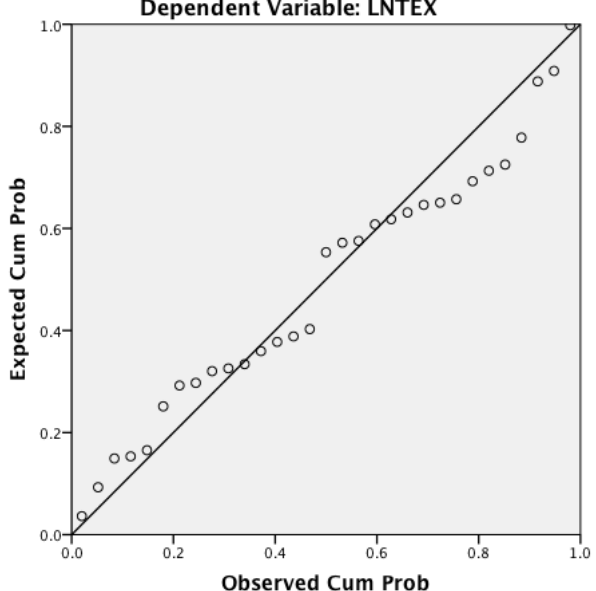

Tests of Normality

\begin{tabular}{|l|r|r|r|r|r|r|}
\hline & \multicolumn{3}{|c|}{ Kolmogorov-Smirnova $^{\text {a }}$} & \multicolumn{3}{c|}{ Shapiro-Wilk } \\
\cline { 2 - 7 } & Statistic & df & \multicolumn{1}{|c|}{ Sig. } & Statistic & df & \multicolumn{1}{c|}{ Sig. } \\
\hline Standardized Residual & .137 & 30 & .157 & .970 & 30 & .535 \\
\hline
\end{tabular}

a. Lilliefors Significance Correction

\section{Appendix Three USA}

Model Summary ${ }^{b}$

\begin{tabular}{|l|r|r|r|c|}
\hline Model & \multicolumn{1}{|c|}{$R$} & R Square & Adjusted R Square & $\begin{array}{c}\text { Std. Error of the } \\
\text { Estimate }\end{array}$ \\
\hline 1 & .997 a & .994 & .993 & .03252 \\
\hline
\end{tabular}

a. Predictors: (Constant), LNGDP2, LNPIT2, LNPIT, Dummy1, LNTEX2, LNGDP

b. Dependent Variable: LNTEX

\section{ANOVAa $^{\mathrm{a}}$}

\begin{tabular}{|ll|r|r|r|r|r|}
\hline Model & & Sum of Squares & \multicolumn{1}{c|}{ df } & Mean Square & F & Sig. \\
\hline \multirow{3}{*}{1} & Regression & 4.487 & 6 & .748 & 707.201 & \\
& Residual & .026 & 25 & $.000^{\mathrm{b}}$ & & \\
& Total & 4.513 & 31 & & & \\
\hline
\end{tabular}

a. Dependent Variable: LNTEX

b. Predictors: (Constant), LNGDP2, LNPIT2, LNPIT, Dummy1, LNTEX2, LNGDP

Coefficients $^{\mathrm{a}}$

\begin{tabular}{|c|c|c|c|c|c|c|}
\hline \multirow{2}{*}{\multicolumn{2}{|c|}{ Model }} & \multicolumn{2}{|c|}{ Unstandardized Coefficients } & \multirow{2}{*}{$\frac{\text { Standardized Coefficients }}{\text { Beta }}$} & \multirow[t]{2}{*}{$\mathrm{t}$} & \multirow[t]{2}{*}{ Sig. } \\
\hline & & $B$ & Std. Error & & & \\
\hline \multirow{7}{*}{1} & (Constant) & -2.320 & 659 & & -3.519 & .002 \\
\hline & LNTEX2 & .262 & .056 & .29 & 4.692 & .000 \\
\hline & Dummy1 & -.391 & .034 & -.37 & -11.414 & .000 \\
\hline & LNPIT & -1.093 & .057 & -.40 & -19.125 & .000 \\
\hline & LNPIT2 & .432 & .077 & .15 & 5.571 & .000 \\
\hline & LNGDP & 1.725 & .253 & 1.26 & 6.811 & .000 \\
\hline & LNGDP2 & -1.080 & .256 & -.81 & -4.226 & .000 \\
\hline
\end{tabular}

a. Dependent Variable: LNTEX 
A.H.G. Kusumah: Tourism Demand Modeling: Price And Income Elasticity

Histogram

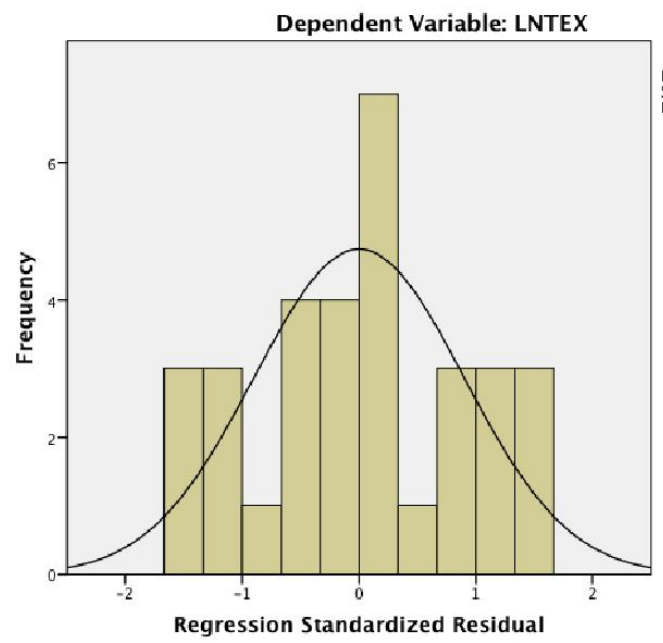

Normal P-P Plot of Regression Standardized Residual Dependent Variable: LNTEX

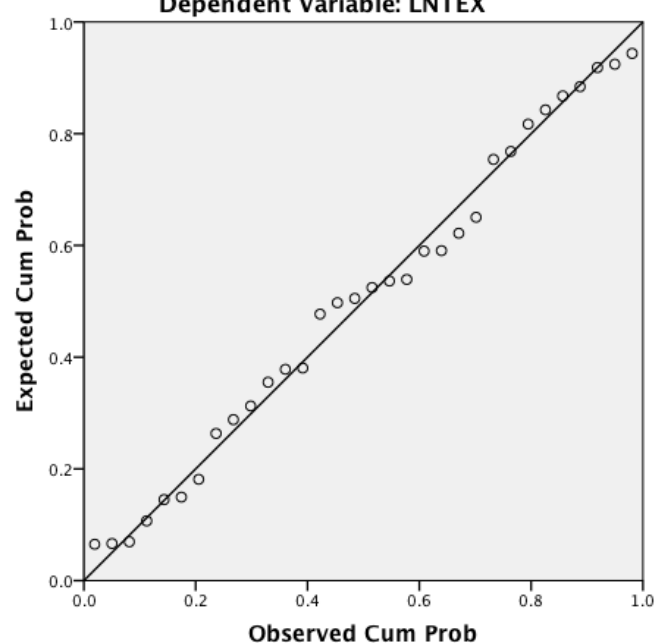

Scatterplot

Dependent Variable: LNTEX

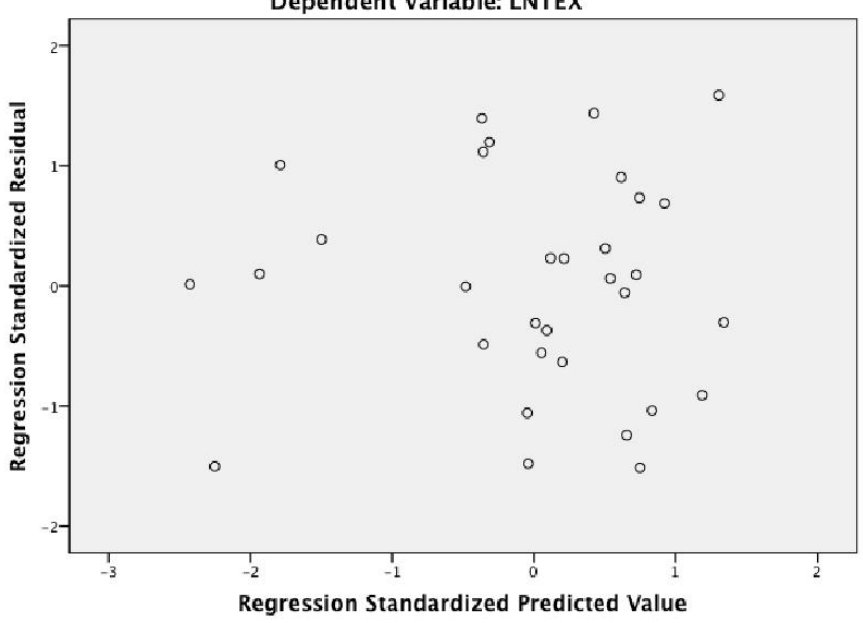

Tests of Normality

\begin{tabular}{|l|r|r|r|r|r|c|}
\hline & \multicolumn{3}{|c|}{ Kolmogorov-Smirnov ${ }^{\mathrm{a}}$} & \multicolumn{3}{c|}{ Shapiro-Wilk } \\
\cline { 2 - 7 } & Statistic & \multicolumn{1}{|c|}{$\mathrm{df}$} & \multicolumn{1}{c|}{ Sig. } & Statistic & $\mathrm{df}$ & \multicolumn{1}{c|}{ Sig. } \\
\hline Standardized Residual & .068 & 32 & .200 & .966 & 32 & .395 \\
\hline
\end{tabular}

${ }^{*}$. This is a lower bound of the true significance.

a. Lilliefors Significance Correction 